\title{
Health of youth is a priority of the modern education
}

\section{Short communication}

The health of children and young people over the last 10years has deteriorated significantly. According to the Health Ministry of Russian Federation (2014), the health of pupils and students decreased by 16$32 \%$ in different age groups. Among high school graduates, there is only a $10-15 \%$ of apparently healthy, whereas more than $60 \%$ has a different level of functional disorders and psycho-emotional stress. Youth receive a wide spread of risk factors such as various forms of addictive behavior, use of alcohol and drugs, back long-forgotten social diseases. ${ }^{1-12}$

In these circumstances the most important direction of domestic policy of any state should be the formation and protection of the health of young people, as the basis for increasing national security. ${ }^{13,14}$

A special role in solving of these problems should play educational organizations where there is an active formation and development of personality. Unfortunately, today we have to admit the fact that modern education system is not yet able to fully implement these tasks. ${ }^{15,16}$

The President of Russia Vladimir Putin at the state Council meeting (13 March, 2013), said: "We are seeing some very worrying trends:-in 14 years two thirds of Russian children already have chronic diseases, half - disturbances in the cardiovascular and respiratory systems, to $40.0 \%$ of recruits unable to perform the minimum standards of physical preparation of servicemen".

That is why the leadership of our country poses the problem of minimizing the impact of demographic and social threats to youth, especially paying attention to the system of their solution in educational institutions.

In that connection it was approved a number of normative legal documents defining the obligation of assessing the health of pupils and students in educational institutions:

A. The Order of the Ministry of Education and Science of the Russian Federation from 12.01.2007, No. 7 defines: "To organize, starting in 2007, conduct annual monitoring of health of pupils in educational institutions";

B. The Order of the Ministry of Education and Science of the Russian Federation from 28.12.2010 No. 2106 "On adoption of Federal requirements for educational institutions concerning the health of students", emphasizes the need to assess the health of schoolchildren in the learning process;

C. The Order of the Ministry of Education and Science of the Russian Federation dated 16.06.2014 No. 658 "About an order of carrying out of socio-psychological testing of persons enrolled in educational institutions and professional educational organizations and educational organizations of higher education" - aimed at early detection of non-medical consumption of narcotic drugs and psychotropic substances.

At the same time the leading link in the mechanism of
Volume 3 Issue 5 - 2017

\author{
Aizman RI \\ Department of Anatomy, Novosibirsk State Pedagogical \\ University, Russia
}

\begin{abstract}
Correspondence:Aizman RI, Doctor of Biological Sciences, Honored Scientist of the Russian Federation, Director of Scientific Research Institute "Health and Safety", Head of the Department of Anatomy, Physiology and Safety of Life, Novosibirsk State Pedagogical University, Russia, Email aizman.roman@yandex.ru
\end{abstract}

Received: May 07, 2017 | Published: June 07, 2017

modernization of Russian education is the teacher, and only a healthy teacher can raise healthy children.

In this regard, the health of teachers is of particular relevance. Personal and professional health of the teacher is one of the factors in the success of the educational system, determines the effectiveness of the training and education of students. The conditions of implementation of innovative educational projects are placing higher demands on professional and personal qualities of teachers, thus strengthening the health of teachers is an integral requirement of the time.

The total assessment of the situation with student's and teacher's health allows us to identify key factors that determine the deterioration of the health of all participants of educational process:

i. Lack of perceived needs in health and healthy lifestyle;

ii. Lack of knowledge on health protection;

iii. Insufficient level of health programs and primary preventive care.

The consequences are a distortion of life, the spread of risk factors of diseases, the formation of behavioral forms leading to lower level of health. These are:

a. Low level of physical activity;

b. An unbalanced diet, leading to impaired intake of iron, iodine and vitamins;

c. Information overload associated with the intensification of training and irrational regime of work, high level of stress;

d. Loyal attitude towards the use of alcoholic and narcotic beverages;

e. Widespread tobacco consumption.

Along with lifestyle factors, we should also highlight the problems of organizational and regulatory plans:

A. The lack of policy documents on protection of health of subjects of the educational process; 
B. The lack of accessible, informative and cheap screening methods for integrated assessment of human health;

C. The lack of preventive work in educational institutions;

D. The lack of integrative approach to health.

The lack of facilities in health care creates a risk to the future of today's students associated with the creation of family, professional and personal growth. It necessitates the development of approaches aimed at assessing and maintaining the level of health of this contingent of the population.

There are many approaches to the evaluation of human's health. The basis of our methodological approach includes the following principles: ${ }^{: 17-19}$

a) Health is a state of complete physical, mental and social wellbeing and not merely the absence of disease or infirmity. This definition is based on the view of an organism integrity and its components which characterize opportunities and ability of the individual to realize their biological, spiritual and social needs at perfect adaptation to external ecological and social conditions. Based on medico-biological positions, we proposed the following definition: "Health is the ability of an organism to maintain homeostasis under conditions of full adaptation to external factors and influences".

b) The level of health can be quantified if we take in account the level of reserve opportunities of the organism providing preservation of a homeostasis of its internal environment during adaptation to constantly changing conditions of the external world (or to loadings).

c) In this regard, one can use different stress tests, allowing to identify the level of reserve capacities of the different systems and the whole organism.

d) The organism and his environment are interrelated, resulting in a mutual influence on each other. The holistic model of health is presented in Figure 1.

e) The child's body is in constant development, so the parameters characterizing his health in ontogenesis change. Therefore, when assessing the health of children and adolescents one must take into account not only the presence or absence of present disease, but first and foremost the developmental dynamics of the physiological processes.

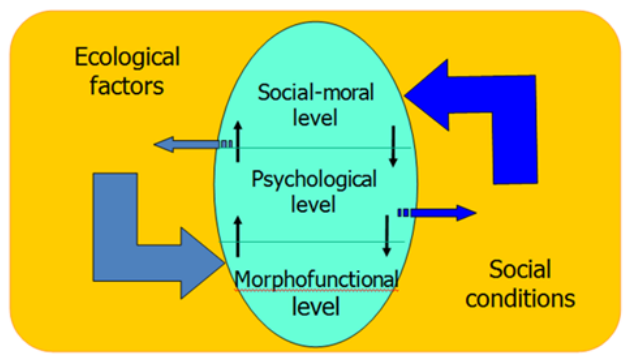

Figure I The holistic model of human's health.

When health monitoring us distinguish the following levels:

A) Morphofunctional (somatic) health, as measured by morphological and functional state of all organs and systems, their interrelation that provides constancy of the internal environment of the body (homeostasis) and its harmonious interaction with the external environment.
B) Psychological (mental) health, including:

I. Adequate self-esteem and sense of self-respect;

II. Ability to adapt to changing conditions of life;

III. Ability to effectively meet their needs and the ability to compensate for those that are impossible to satisfy at the moment;

IV. A person's confidence that he is controlling his life;

V. Gender identity, socialization and self-realization.

Thus, mental health involves total emotional comfort, adaptability and effective self-control that has a significant impact on quality of life, emotional, cognitive, personality, and gender identity.

C) Social-moral health is determined by:

i. Adherence to moral and ethical principles, shaped by mankind.

ii. Compliance with legal standards and laws of the society.

In characterizing the health is of an importance the integrative approach that takes into account the complex of all parameters. Each of the components of health can be evaluated by objective indicators (Table 1).

Table I Indicators of individual health of the person

\begin{tabular}{|c|c|c|}
\hline $\begin{array}{l}\text { Components } \\
\text { of health }\end{array}$ & Criteria of health & Indicators of health \\
\hline \multirow{4}{*}{$\begin{array}{l}\text { Morpho } \\
\text { functional } \\
\text { (Somatic) } \\
\text { health - } \\
\text { determines the } \\
\text { capabilities of } \\
\text { the body }\end{array}$} & Genetic & Genotype \\
\hline & Biochemical & Indicators of biological fluids \\
\hline & Morphological & $\begin{array}{l}\text { The level of physical } \\
\text { development, morphotype }\end{array}$ \\
\hline & Functional & $\begin{array}{l}\text { The functional state of } \\
\text { organs and systems at rest } \\
\text { and after loadings, functional } \\
\text { type }\end{array}$ \\
\hline
\end{tabular}

$\begin{array}{lll}\begin{array}{l}\text { Psychological } \\ \text { (Mental }\end{array} & \begin{array}{l}\text { Emotional-volitional } \\ \text { health)- }\end{array} & \begin{array}{l}\text { sphere; } \\ \text { of the brain, the type } \\ \text { of high nervous system, } \\ \text { psychological type, }\end{array} \\ \begin{array}{l}\text { Provides the } \\ \text { desire of the }\end{array} & \begin{array}{l}\text { sphere; Personal } \\ \text { individual }\end{array} & \begin{array}{l}\text { temperament, level of } \\ \text { anxiety, stress resistance, } \\ \text { memory, attention, thinking, } \\ \end{array} \\ & \begin{array}{l}\text { mental performance, } \\ \text { personal qualities. }\end{array}\end{array}$

Social and moral (Spiritua health)-

Adherence to ethical and defines human legal norms Purpose, values, ideals, degree recognition, implementation of desires and possibilities- degree of self-realization

responsibilities

These principles formed the basis of the developed programs for assessment of health of pupils and students of secondary and higher educational institutions-health passports. The main purpose of these programs is diagnosis of the physical, mental, and spiritual health, and physical fitness for the of quantitative health characteristics according to the age, gender, social groups, etc.

Goal of this diagnostics: based on the data on individual characteristics and possibilities of the human to provide: 
i. Health preservation in the process of individual development and learning;

ii. Professional orientation of pupils for informed and adequate choice of occupation;

iii. Assessment of individual psycho-physiological, typological and personal characteristics of the student to timely correction and development of professionally significant qualities;

iv. Assessment of health oriented activities of educational institutions;

v. Identification of addictive behavior risk groups.

These electronic passports of health have the following advantages: ${ }^{20}$

a. Integrative approach to health as a system including indicators of physical, mental and social levels;

b. Computerization of all data that allows to create bank of health of various age, gender, and occupational groups;

c. Quantitative expression of indicators which provides possibility of dynamic control and comparison of health levels of various groups, educational institutions, districts, etc;

d. The relative ease of the survey, which does not require expensive equipment;

e. The transferability of the results of the survey via the Internet;

f. Involvement of the subject in the process of examination that increases his personal interest in the preservation and development of health;

g. The ability to predict the risk of development of addictive behavior in a timely manner to reveal psycho-somatic violations and to carry out their correction.

With the help of these electronic passports it was surveyed more than 60,000 pupils and students of different age and gender, allowing evaluating the influence of educational and sports activities on physical and mental health, to give individual recommendations to correct certain deviations. Such an electronic passport can be easily implemented in all educational institutions.

\section{Acknowledgements}

None.

\section{Conflict of interest}

Author declares that there is no conflict of interest.

\section{References}

1. Kuznetsova LM, Kuznetsov VD, Timoshenko KT. Indicators of mental health of high school students and University students. Hygiene and sanitation. 2008;3:59-63.

2. Negasheva MA, Mishkova TA. Anthropometric parameters and adaptive capabilities of students to the beginning of the XXI century. Russian Pedagogical Journal. 2005;5:12-16.
3. Klimov VM, Aizman RI. Assessment of the physical health of high school graduates enrolled in higher education. Bulletin of Siberian Medicine. 2016;15(3):41-47.

4. Sukhareva LM, Rapoport IK, Zvezdin TV. Health and physical activity of modern school children. Hygiene and sanitation. 2002;3:52-55.

5. Chokotov EN, Grigorchuk YV, Nikulin OS, et al. Morphofunctional and psychological reserves and cadets in the initial period of education. Vestnik of the Novosibirsk state pedagogical University. 2015;3:102-111.

6. Kuzhuget AA, Rubanovich VB, Aizman RI. The indexes of physical health of students depending on kind of sports activity and level of qualification. Health saving education. 2011;6(18):105-108.

7. Ondar AO, Ondar SO, Aizman RI. The comparative characteristics of the level of physical health and physical preparedness of the 1-st year students of Tuv SU. Bulletin of the Novosibirsk State Pedagogical University. 2013;10(4):68-79.

8. Lebedev AV, Rubanovich VB, Aizman NI, et al. Morphofunctional features of the first-year students of a pedagogical university. Bulletin of the Novosibirsk State Pedagogical University. 2014;17(1):128-141.

9. Aizman RI, Lebedev AV, Aizman NI, et al. Psychophysiological and personal characteristics of the first-year students of a pedagogical university. Siberian Pedagogical Journal. 2013;6:244-251.

10. Chanchaeva EA, Aizman RI, Sidorov SS. Gender variability of morphofunctional indices of adolescents in Gorny Altai. Hygiene and sanitation. 2016;95(3):269-273.

11. Lebedev AV, Galai IA, Aizman NI, et al. The personal potential of the students of the 1st year of education. Siberian Pedagogical Journal. 2015;1:69-73.

12. Galai IA, Lebedev AV, Aizman RI. The features of personal potential of students in the city and the regional centre. Bulletin of the Novosibirsk State Pedagogical University; 2015;3:94-101.

13. Makarova LP, Bujnov LG, Peterkin MV. Maintaining the health of students is a pedagogical problem. Modern Problems of Science and Education. 2012;4:242-247.

14. Aizman RI. Health of teachers and schoolchildren is a key problem of modern school. Bulletin of the Novosibirsk State Pedagogical University. 2012;3(7):24-35.

15. Aizman RI, Kazin EM, Fedorov AI, et al. Problems and aims of health care activity in the education system at the present stage. Bulletin of the Novosibirsk State Pedagogical University. 2014;17(1):9-17.

16. Kazin EM. Health-saving infrastructure in the education system:a tutorial. Moscow: Omega-L; 2015. 442p.

17. Aizman RI. Modern views on health and criteria for its evaluation. Siberian Pedagogical Journal. 2012;9:85-90.

18. Gerasev AD, Aizman RI, Lebedev AV, et al. System health monitoring, personal potential and the risk of mental dependency formation at students of pedagogical high school. Pedagogical Education and Science. 2013;5:65-69.

19. Aizman RI. Health of participants of educational process as a criterion of effectiveness of health care activity in the education system. Domestic and Foreign Pedagogy. 2015;26(5):72-82.

20. Aizman RI, Lebedev AV, Aizman NI, et al. Methodology and practice of monitoring the health of students. Health and Education in the XXI-st century. 2017;19(5):73-79. 